\title{
Production of Spores of Trichoderma harzianum on Sugar Cane Molasses and Bagasse Pith in Solid State Fermentation for Biocontrol
}

\author{
Jose A. Rodríguez-León, ${ }^{1 *}$ F. Domenech, ${ }^{1}$ M. León, ${ }^{1}$ T. Méndez, ${ }^{1}$ D. E. Rodríguez ${ }^{1}$ and \\ Ashok Pandey ${ }^{2}$ \\ ${ }^{1}$ Instituto Cubano de Investigaciones de los Derivados de la Caña de Azúcar (ICIDCA), P.O. Box 4026, La \\ Habana, Cuba; ${ }^{2}$ Laboratorio de Processos Biotecnologicos, Departamento de Engenharia Quimica, \\ Universidade Federal do Parana, CEP 81531-970, Curitiba-PR, Brazil
}

\begin{abstract}
Solid state fermentation was carried out for the production of spores from Trichoderma harzianum No 53 using sugar cane bagasse pith as solid matrix and sugar cane molasses as carbon and energy source. Different nitrogen sources such as urea, $\left(\mathrm{NH}_{4}\right)_{2} \mathrm{SO}_{4}, \mathrm{NH}_{4} \mathrm{H}_{2} \mathrm{PO}_{4}$ and $\left(\mathrm{NH}_{4}\right)_{2} \mathrm{HPO}_{4}$ were added in the media to test their effect on spores production. Among these, urea was found most useful that resulted high no of spores $\left(1 \times 10^{9} / g D M\right)$. The influence of temperature and initial moisture of the substrate was studied through a $2^{2}$ experimental plan design. No statistical differences were found within the range of $30-35^{\circ} \mathrm{C}$ and $60-70 \%$ for temperature and moisture respectively. The biotechnological parameters of the process were derived from the Oxygen Uptake Rate (OUR) pattern, which corresponded to the order of $10^{9} \mathrm{spores} / \mathrm{g}$ moist material. The specific growth rate, maintenance coefficient and the yield based on $\mathrm{O}_{2}$ consumption were $0.108 \mathrm{~h}^{-1}, 0.001$ g. $\mathrm{O}_{2} /$ g.biomass.h and $2.7 \mathrm{~g}$ biomass $/ \mathrm{g} \mathrm{O}_{2}$ consumed, respectively.
\end{abstract}

Key words: Trichoderma harzianum, solid state fermentation, sugar cane pith and molasses, biocontrol, kinetics

\section{INTRODUCTION}

In the last few years, the significance of biological control and pest management has been well illustrated by several authors (Elad \& Chet, 1995; Hokkanen, 1994; Lacey \& Goettel, 1995; Leggett \& Gleddie, 1995; Moore \& Prior, 1993; Sutton \&. Peng, 1993). There are associated benefits and the risks of the employment of micro-organisms against unwanted organisms (target pests). Although the products from Bacillus thuringiensis are by far the most applied nowadays, there are some biofungicides that are marketed at present. Such a product has been prepared from Trichoderma sp also (Hokkanen, 1994; Fokkema, 1996).

There has been rapid development on the procedures for the production of micro-organisms to be employed in biocontrol.
Trichoderma sp. is considered as a promising source for the production of bioplaguicides for the control of different plagues like Botrytis cinerea, Fusarium sp., Phytophtora sp., Rhizoctonia solani and Sclerotium rolfsii (Belanger et al., 1995; Bonilla, 1990; Dickinson et al., 1995; Echemendía et al., 1995; Goldman et al., 1994; Lewis \& Lumsden, 1995; Lorito et al., 1996; Mao et al., 1997; Orlikowsi, 1995). However, in case of fungi, there is general lack of efficient technologies for commercial production. One of the main reasons for this being their tendency is to form pellets in submerged fermentation, which is traditionally employed to produce spores.

Solid state fermentation (SSF) offers numerous advantages over liquid fermentation (Pandey, 1991, 1992, 1994) and could be an attractive alternative for this. SSF has been

Author for correspondence 
considered a useful system for spores production (Cliquet \& Scheffer, 1997; Muñoz et al., 1995; Roussos, 1987). However, little is known about the kinetics of SSF processes that hinders further development and scale-up of particular processes and their consequent technologies. In that sense, it seems to be of paramount importance to determine the process parameters to assess system charac-terization for complete process description. In case of fungal cultures like Trichoderma sp., if to be used for spore production, it would be important to use such media that does not induce fungal activity of enzyme formation but support mycelial growth and sporulation.

In this paper we report our results on the cultivation of Trichoderma harzianum No 53 in a medium, balanced as a function of sugar present as well as on the supplementation of medium with different nitrogen and phosphorus sources in an aerated solid state fermentation on bagasse pith matrix enriched with sugar cane molasses. Process kinetics were determined through Oxygen Uptake Balance (OUR), as has been previously described (Rodríguez et al., 1998; Sato et al., 1983; Soccol et al., 1993).

\section{MATERIALS AND METHODS}

Microorganism: The study was carried out with the strain of Trichoderma harzianum No 53 obtained from the National Institute for Research on Plant Health (INISAV, Cuba).

Inoculum: Inoculum was prepared by growing the culture in Czapek medium at $30^{\circ} \mathrm{C}$ for $48 \mathrm{~h}$ under static conditions. Mycelia (10\%, wet wt. basis), so obtained, were used as inoculum.

Substrate: Sugar cane molasses (density 1.43 $\mathrm{g} / \mathrm{ml}$, sugar concentration 53\%) was mixed with bagasse pith in 1:1 (w/w) ratio. This amount was calculated to prevent percolation to achieve a final concentration of $37 \%$ of total sugars based on dry bagasse pith (21\% based on initial dry total weight). Bagasse pith was previously sieved through a 3-mm sieve. Initial $\mathrm{pH}$ and moisture of the substrate were adjusted to 5.1 and $60 \%$, respectively.

Fermentation: Fermentation was carried out in glass columns $(100-\mathrm{ml})$ as described by Raimbault (1981). It was aerated with a saturated air at $1 \mathrm{VKgM}$ (1 air/substrate $\mathrm{kg} / \mathrm{m})$. The studied nitrogen sources were urea, (NH4) $)_{2} \mathrm{SO}_{4}, \mathrm{NH}_{4} \mathrm{H}_{2} \mathrm{PO}_{4}$ and $\left(\mathrm{NH}_{4}\right)_{2} \mathrm{HPO}_{4}$. Their concentration was decided by the amount of nitrogen required for $50 \%$ uptake of total sugars and $30 \%$ of true protein (on dry matter basis) in microbial biomass. All fermentations were carried out at $30^{\circ} \mathrm{C}$.

Influence of temperature and moisture: $\mathrm{A}$ factorial experimental design $\left(2^{2}\right)$ with a substrate formulation, which gave the best results in the experiments with different nitrogen sources, was carried out to study the influence of temperature and moisture. Independent variable levels were $30^{\circ} \mathrm{C}$ (low level) and $35^{\circ} \mathrm{C}$ (high level), and $60 \%$ (low level) and 70\% (high level) for temperature and moisture, respectively. Runs were carried out in triplicate in random blocks corresponding to the temperature of $30^{\circ} \mathrm{C}$ and in duplicate for the block corresponding to $35^{\circ} \mathrm{C}$. The time of fermentation in all the cases was 5 days with aeration saturated with water vapours.

Determination of the process kinetics: The consumed $\mathrm{O}_{2}$ and the $\mathrm{CO}_{2}$ evolved was monitored during the whole process by gas chromatography (Gow-Mac equipment) with a thermal conductivity detector and a concentric column CTR-1 (Alltech, USA).

Counting of spores: Spores counting was done in a Neubauer chamber.

Protein determination: Protein was determined by Barnstein method (Winton \& Winton, 1944). A sample of $0.7 \mathrm{mg}$ was treated with concentrated $\mathrm{H}_{2} \mathrm{SO}_{4}$ and after digestion $\mathrm{Cu}(\mathrm{OH})_{2}$ was added. The protein precipitate was washed thoroughly and nitrogen was determined by the Kjeldahl method. 


\section{RESULTS AND DISCUSSION}

Table I shows the results obtained for spores counting after 5 days of fermentation in the substrates with different nitrogen sources tested. As is apparent, there was no statistical difference between urea and ammonium dihydrogen-phosphate with a $95 \%$ of confidence level. This suggested a positive effect of both of these compounds on the microbial culture for spore production. The low values exhibited by ammonium sulfate and diammonium hydrogen phosphate could probably be due to a sharp decrease of $\mathrm{pH}$ regardless its possible metabolic influence.

Table 1. Final counting of spores as a function of the nitrogen source employed for the spore production from Trichoderma harzianum No. 53

\begin{tabular}{|c|c|}
\hline & No. Spores/g dried matter \\
\hline Urea & $1.6 \times 10^{9}$ \\
\hline$\left(\mathrm{NH}_{4}\right)_{2} \mathrm{SO}_{4}$ & $1.0 \times 10^{8}$ \\
\hline$\left(\mathrm{NH}_{4}\right) \mathrm{H}_{2} \mathrm{PO}_{4}$ & $0.9 \times 10^{9}$ \\
\hline$\left(\mathrm{NH}_{4}\right)_{2} \mathrm{HPO}_{4}$ & $0.9 \times 10^{8}$ \\
\hline
\end{tabular}

The response matrix obtained from the factorial design $2^{2}$ respect to the final spore counting as a function of temperature and initial moisture was: $6.91 \times 10^{9}, 5.18 \times 10^{9}, 4.06 \times 10^{9}, 384 \times$ $10^{9}$.

The discrimination of the coefficients corresponding to the model of the experimental design was carried out by the Fischer's test (Bacon, 1971), considering a $s_{p}=2,06 \times 10^{9}$ calculated from the replicated runs, with 6 degrees of freedom and at a $95 \%$ confidence level (for a $C_{\text {ritical }}=5,99$ ). The results are shown in Table II, where $b_{o}$ is the mean value of the block, $b_{1}$ and $b_{2}$ are the corresponding coefficients for temperature and initial moisture, respectively. $b_{12}$ is the coefficient that represents the interaction between the former factors studied.

From this design, it could be deducted that although none of the two factors were significant, it was convenient to work at the lowest levels of moisture $(60 \%)$ and temperature $\left(30^{\circ} \mathrm{C}\right)$ tested for two reasons; first to prevent bacterial contamination that could occur at higher moisture levels, and secondly, keeping due to the fact that uncontrolled processes the temperature increase could delay the normal development of the culture.

Table 2. Factor discrimination for spore counting corresponding to the $2^{2}$ factorial design as function of temperature and moisture

\begin{tabular}{|c|c|l|c|}
\hline & $\mathrm{b}_{\mathrm{i}}$ & $\begin{array}{l}\mathrm{F}= \\
\mathrm{b}_{\mathrm{i}}{ }^{2} / 1 / 4 \mathrm{~s}_{\mathrm{p}}{ }^{2}\end{array}$ & $\mathrm{~F} / \mathrm{F}_{\text {critical }}$ \\
\hline $\mathrm{b}_{\mathrm{o}}$ & $5,00 \times 10^{9}$ & 23.564 & 4 \\
\hline $\mathrm{b}_{1}$ & $-0,49 \times 10^{9}$ & 0,23 & 0.04 \\
\hline $\mathrm{b}_{2}$ & $-1,05 \times 10^{9}$ & 1,04 & 0.17 \\
\hline $\mathrm{b}_{12}$ & $0,38 \times 10^{9}$ & 0,14 & 0.07 \\
\hline
\end{tabular}

The conditions tested here were far to be optimum provided that the interaction between temperature and initial moisture has no significance and showed the lowest coefficient value $\left(b_{12}\right)$. These results suggested that the optimum value for initial moisture could be below $60 \%$ and for temperature less than $30^{\circ} \mathrm{C}$ (taking into account the negative which showed declining trends afterwards to a minimum around $37-38 \mathrm{~h}$ when the micro-organism started to sporulate.

To solve this equation, only the values obtained within the first $38 \mathrm{~h}$ were considered. The values corresponding to yield based on oxygen consumption $\left(\mathrm{Y}_{\mathrm{ox}}\right)$, maintenance coefficient $(\mathrm{m})$ and the estimation of biomass at each point $\left(\mathrm{X}_{\mathrm{i}}\right)$ that corresponded to this process were obtained by a trial and error procedure as reported by Rodriguez-León et. al. (1998) and Soccol et al. (1993). This trial and error was made from an initial biomass $\left(\mathrm{X}_{0}\right)$ of $2.5 \mathrm{~g}$ estimated by protein determination, considering $30 \%$ protein concentration in biomass (dry basis) and a final biomass concentration at $38 \mathrm{~h}$ as $8.9 \mathrm{~g}$.

The Oxygen Uptake Rate (OUR) during fermentation is shown in Figure 1. A lag phase of about 15-h was observed, and before this time no oxygen uptake was detected. OUR profile exhibited a maximum at $21 \mathrm{~h}$, which showed declining trends afterwards to a minimum around $37-38 \mathrm{~h}$ when the microorganism started to sporulate. To solve this equation, only the values obtained within the first $38 \mathrm{~h}$ were considered. The values corresponding to yield based on oxygen 


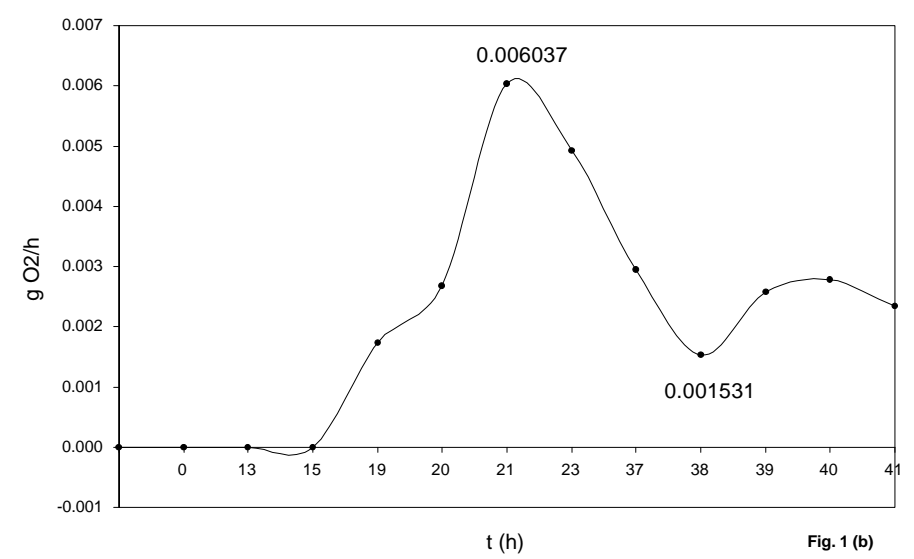

Figure 1. Kinetics of OUR during SSF of sugarcane bagasse by T. harzianum

The kinetic parameters were determined by means of the equation:

$$
X_{n}=\frac{Y_{o x} \Delta t\left[1 / 2\left(R_{o}+R_{n}\right)+\sum_{i=1}^{n-1} R_{i}+\left(1-\frac{a}{2}\right) X_{o}-a \sum_{i=1}^{n-1} X_{i}\right.}{1+a / 2}
$$

Where:

$\mathrm{a}=\mathrm{Y}_{\mathrm{ox}} \mathrm{m} \Delta \mathrm{t}$

$\mathrm{X}_{\mathrm{o}}$ : initial biomass $(\mathrm{g})$.

$\mathrm{X}_{\mathrm{i}}$ : biomass at time $\mathrm{t}_{\mathrm{n}}(\mathrm{h})$.

$\mathrm{Y}_{\mathrm{ox}}$ : yield based on consumed oxygen ( $\mathrm{g}$ biomass / $\mathrm{g} \mathrm{O}_{2}$ consumed).

$\mathrm{R}_{\mathrm{o}}$ : initial oxygen uptake rate $\left(\mathrm{g} \mathrm{O}_{2} / \mathrm{h}\right)$.

$\mathrm{R}_{\mathrm{i}}$ : oxygen uptake rate at time $\mathrm{t}_{1}\left(\mathrm{~g} \mathrm{O}_{2} / \mathrm{h}\right)$.

$\mathrm{m}$ : maintenance coefficient $\left(\mathrm{g} \mathrm{O}_{2} / \mathrm{g}\right.$ biomass / $\left.\mathrm{h}\right)$.

$\Delta \mathrm{t}: \quad$ time interval $(\mathrm{h})$.

Table 3. Kinetics parameters corresponding to solid state fermentation of sugar cane molasses on bagasse pith by the strain Trichoderma harzianum No 53

\begin{tabular}{|cll|}
\hline $\mathrm{Y}_{\mathrm{ox}}:$ & 2.7 & $\mathrm{~g}$ biomass $/ \mathrm{g} \mathrm{O}_{2}$ consumed \\
\hline $\mathrm{m}:$ & 0.001 & $\mathrm{~g} \mathrm{O}_{2}$ consumed/g biomass $/ \mathrm{h}$ \\
\hline$\mu:$ & 0.108 & $\mathrm{~h}^{-1}$ \\
\hline $\mathrm{r}:$ & 0.996 & \\
\hline $\mathrm{X}_{\mathrm{n}}$ determined at 37 h analytically & 8.9 & $\mathrm{~g}$ \\
\hline $\mathrm{X}_{\mathrm{n}}$ estimated by equation $(1)$ at $37 \mathrm{~h}$ & 8.7 & $\mathrm{~g}$ \\
\hline
\end{tabular}

consumption $\left(\mathrm{Y}_{\mathrm{ox}}\right)$, maintenance coefficient $(\mathrm{m})$ and the estimation of biomass at each point $\left(\mathrm{X}_{\mathrm{i}}\right)$ that corresponded to this process were obtained by a trial and error procedure as reported by Rodriguez-León et. al. (1998) and Soccol et al. (1993). This trial and error was made from an initial biomass $\left(\mathrm{X}_{0}\right)$ of $2.5 \mathrm{~g}$ estimated by protein determination, considering $30 \%$ protein concentration in biomass (dry basis) and a final biomass concentration at $38 \mathrm{~h}$ as $8.9 \mathrm{~g}$.

The results obtained by the trial and error process are reported in Table 3 . The specific 
growth rate, $(\mu)$ was estimated from the values of $X_{i}$ for each time corresponding to the $\log$ phase. The regression coefficient ( $r$ ) reported corresponded to this estimation.

These results indicated good values for the yields based on consumed oxygen $\left(\mathrm{Y}_{\mathrm{x} / \mathrm{o}}\right)$, as well as for maintenance coefficient (m). Such a low value for $(\mathrm{m})$ could be related with a process in which no inducible enzymes were produced, in spite of the fact that Trichoderma sp. are well known as producers of cellulolytic and xylanolytic enzymes. The whole microbial energy was employed to grow from the sugars. This behavior seemed to be related to initial repression of those enzymes, by sugars content and the corresponding nitrogen balance as function of the initial sugars. This meant that if the nitrogen was not balanced, it could be expected that the strain would produce cellulases or xylanases and therefore the time to reach the appropriate spore counting could be much longer and maintenance coefficient would be higher with the concomitant decrease of oxygen based yield.

\section{CONCLUSIONS}

The results demonstrated that a good sporulation from Trichoderma harzianum could be achieved in only 5 days. It could be interesting to further study the sporulation behavior at moisture levels below $60 \%$, which could result higher productivity of spores in aerated solid state fermentation system.

\section{ACKNOWLEDGMENTS}

The present work was partially financed by the National Technical and Scientific Program from CITMA, Agriculture Branch, Program No. 0.03.00.004. We thank Professor Dr. Carlos R. Soccol for helping to prepare the Portuguese Resumo of the paper.

\section{RESUMO}

Esporos de Tricoderma harzianum $\mathrm{N}^{\mathrm{o}} 53$ foram produzidos por fermentação no estado sólido (FES) utilizando bagaço de cana como suporte e melaço de cana como fonte de carbono. Diferentes fontes de nitrogênio foram testadas (uréia, $\left(\mathrm{NH}_{4}\right)_{2} \mathrm{SO} 4, \mathrm{NH}_{4} \mathrm{H}_{2} \mathrm{PO}_{4} \mathrm{e}$ $\left.\left(\mathrm{NH}_{4}\right)_{2} \mathrm{HPO}_{4}\right)$ na produção de esporos. As mais elevadas concentrações de esporos $\left(10^{9}\right.$ esporos/g de suporte úmido) foram obtidas utilizando a uréia como fonte de nitrogênio. $\mathrm{O}$ efeito da temperatura e umidade inicial foram estudadas através da utilização da planificação experimental utilizando um modelo $2^{2}$. Não foi encontrada diferença estatística na produção de esporos na faixa de temperatura compreendida entre $30-35{ }^{\circ} \mathrm{C}$ e umidade inicial de 60-70\%. Os parâmetros biotecnológicos foram determinados através da taxa de oxigênio consumido (OUR) correspondente a uma produção de $10^{9}$ esporos/g de suporte úmido. A taxa de crescimento especifico, coeficiente de manutenção e rendimento foram calculados em função do $\mathrm{O}_{2}$ consumido, cujos valores foram $0.108 \mathrm{~h}-1,0.001 \mathrm{~g} \mathrm{O}_{2} / \mathrm{g}$ biomassa/h e $2.7 \mathrm{~g}$ biomassa/g $\mathrm{O}_{2}$ consumido respectivamente.

\section{REFERENCES}

Bacon, D. W. (1971) Statistical design and model building. Ed. Dept. Chem. Eng., Queens University, Kingston, Canada

Belanger, R. R., Dufour, N., Caron, J. \& Benhamou, N. (1995) Chronological events associated with the antagonistic properties of Trichoderma harzianum against Botrytis cinerea: indirect evidence for sequential role ofantibiosis and parasitism. Biocontrol Sci Technol, 5, 4153

Bonilla, M. H. (1990) Utilizaçao de especies de Trichoderma no controle biologico de Fusarium moniliforme var. subglutinans Ws. y Rg. Msc Thesis, Universidad Federal de Bahia, Brazil.

Cliquet, S. and Scheffer, R. J. (1997) Influence of culture conditions on growth and survival of conidia of Trichoderma spp. 
coated on seeds. Biocontrol Sci Technol, 7, 171-181

Dickson, J. M.., Hanson, J. R. and Truneh, A.(1995) Metabolites of some biological control agents. Pestic. Sci., 44, 389-393

Echemendia, M., Perez, N. and Yalixetti, O. (1995) Biological Aspects of Trichoderma spp. and its possible use as biocontrol. Bioplag 95. INIFAT, Habana, Cuba

Elad, Y. and Chet, I. (1995) Practical approaches for biocontrol implementation. In- Novel Approaches to Integrated Pest Management, Ed. Lewis Publishers Inc, Boca Raton, FL, USA, pp. 323-338

Fokkema, N. J. (1996) Biological control of fungal plant diseases. Entomophaga, 41, 333-342

Goldman, G. H., Hayes, C. and Harman, G. E. (1994) Molecular and cellular biology of biocontrol by Trichoderma sp., TIBTECH, 12, 478-482

Hokkanen, H. M. T. (1994) Pest management, Biological control. Encyclopedia of Agricultural Science, 3, 155-167

Lacey, L. A. and Goettel, M. S. (1995) Current developments in microbial control of insect pests and prospects for the early 21 st century. Entomophaga, 40, 3-27

Leggett, M. E. and Gleddie, S. C. (1995) Developing biofertilizer and biocontrol agents that meet farmers' expectations. $A d v$ in Plant Pathol, 11, 59-74

Lewis, J. A. and Lumsden, R. D. (1995) Do pathogenic fungi have the potential to inhibit biocontrol fungi? J Phytopathol Phytopathologische Zeitschrift, 143, 585588

Lorito, M.., Woo, S. L., D'Ambrosio, M., Harman, G. E., Hayes, C. K., Kubicek, C. P. and Scala, F. (1966) Synergistic interaction between cell wall degrading enzymes and membrane affecting compounds.Mole Plant-Microbe Interaction, 9, 206-213

Mao, W., Lewis, J. A., Hebbar, P. K. and Lumsden, R. D. (1997) Seed treatment with a fungal or a bacterial antagonist for reducing corn damping-off caused by species of Pythium and Fusarium. Plant Disease, 81, 450-454
Moore, D. and Prior, C. (1993) The potential of mycoinsecticides. Biocontrol News and Information, $14,31 \mathrm{~N}-40 \mathrm{~N}$

.Munoz, G. A., Agosin, E., Cotoras, M., Sanmartin, R.and Volpe, D. (1995) Comparison of aerial and submerged spore properties for Trichiderna harzianum. FEMS Microbiol Lett, 125, 63-70

Orlikowski, L. B. (1995) Studies on the biological control of Phytophthora Cryptogea Pethybr Et Laff. Ii. Effectiveness of Trichoderma and Gliocladium spp in the control of Phytophthora foot rot of gerbera. $J$ Phytopathol - Phytopathologische, 143, 341-343

Pandey, Ashok (1991) Aspects of design of fermenter in solid state fermentation, Process Biochem., 26, 355-361

Pandey, Ashok (1992) Recent developments in solid state fermentation, Process Biochem., 27, 109-117

Pandey, Ashok (1994), Solid state fermentation. In- Solid State Fermentation. ed. A. Pandey, Wiley Eastern Publishers, New Delhi, India, pp. 3-10

Raimbault, M. (1981) Fermentation en milieu solide croissance des champignons filamen-teux sur substrat amylacé. Travaux et Documents de l'ORSTOM., No. 127. Paris, France

Rodriguez Leon, J. A., Sterz, S. C., Soccol, C. R. and Raimbault, M. (1998) Kinetics of the solid state fermentation of raw cassava flour by Rhizopus formosa 28422. In- Proc Internatl Course Solid State Fermentation. eds. M. Raimbault, C. R. Soccol and G. Chuzel, Document ORSTOM, No. 1, Montpellier, pp. 103-110

Roussos, S. (1987) Croissance de Trichoderma harzianum par fermentation en milieu solide: Physiologie, sporulation et production de cellulases. Coll. Etudes et Theses. Ed. ORSTOM. París, France

Sato, K., Nagatani, M., Nakamura, K. and Sato, S. (1983) Growth estimation of Candida lipolitica from oxygen uptake in a solid state culture with forced aereation. $J$. Ferment. Technol., 61, 623-629 
Soccol, C. R, Rodriguez Leon, J. A., Raimbault, M. and Roussos, S. (1993) Growth kinetics of Rhizopus arrizhus in solid state fermentation of treated cassava. Biotechnol Tech, 7, 563-568

Sutton, J. C. and Peng, G. (1993) Manipulation and vectoring of biocontrol organisms to manage foliage and fruit diseases in cropping systems. Ann. Rev. Phytopathol., 31, 473-493
Winton, A. L. and Winton, K. B. (1983) Métodos químicos generales: Proteínas. In- Análisis de los Alimentos. Editorial Pueblo y Educación, Habana, Cuba, pp. 84

$$
\begin{array}{r}
\text { Received: July 24, 1998; } \\
\text { Revised: July 24,1998; } \\
\text { Accepted: February 12, } 1999 .
\end{array}
$$

